\title{
Prevalence of Bovine viral diarrhea virus in cattle herds from Basrah and Nassirya Provinces by direct and indirect Elisa and Real time qPCR
}

\author{
B. A. Jarullah \\ Unive. of Trakia / Bulgaria
}

\author{
J. Aed Gati \\ Vet. Hospital/Thi-Qar \\ province
}

\author{
A. Saleh \\ Coll. of Nursing / Unive. of \\ Thi-Qar
}

\begin{abstract}
The current study was conducted to investigate the prevalence of BVD virus in Basrah and Nassirya city by using ELISA and RT-PCR. Two hundreds and eighty two samples of non vaccinated cattle sera samples collected from two regions of Iraq (188 samples from Nassirya city and 92 samples from Basrah city). Samples tested by Enzyme Linked Immunosorbent Assay (ELISA) antigen capture. Positive results were 20 samples ( 8 sample in Thi-Qar and 12 positive samples from Basrah). All samples submitted to indirect ELISA(IDEXX HerdCheck ELISA )for detect BVDV antibodies .Genotyping of all 20 positive samples to antigen detection were tested by Real time PCR, using Cador BVDV $1 / 2$ kit, after extraction of virus RNA by QIAamp mini kit. The results revealed that there were 20 positive sample according to direct ELISA(Ag detection), while 66 sample were positive to indirect ELISA, as well as, the result of RT-PCR showed that there were two sample positive to BVDV type-1 (one sample form each city).

Key words: BVDV, Genotype, ELISA, Iraq, Real time PCR.
\end{abstract}

\section{Introduction}

Bovine viral diarrhea virus (BVDV) is an important pathogen of cattle which causes significant economic losses to the livestock industry around the world (1). BVDV is a small enveloped RNA virus belonging to the Flaviviridafamily, genus Pestivirus, along with classical swine fever virus and border disease virus of sheep $(1,2)$. BVDV has many different manifestations in a herd, depending on the herd's immune and reproductive status. Transient diarrhoea, mixed respiratory infection, infertility or abortion and mucosal disease are the most common clinical signs of the disease and can be seen simultaneously in a herd. The BVDV genome is a linear, single-stranded, positive sense RNA molecule of approximately $12.5 \mathrm{~kb}$ in length (3).The genome contains a single large open reading frame (ORF) encoding a polyprotein of about 3900 amino acids. The ORF is flanked by a 5' 381-386-nucleotide long untranslated region (5'UTR) and by a 3' 229-nucleotide secondary structure believed to act as an internal ribosomal entry site to direct the translation of the ORF upon internalization of the viral genome into the host cell (4). Translation of the ORF produces a long polyprotein, which is co- and posttranslationally processed by viral and cellular proteases giving rise to 11 to 12 mature viral proteins $(3,5)$. The structural proteins (the exception is $\mathrm{N}^{\text {pro }}$, a nonstructural protein) are encoded by the 5 ' third of the genome as follows: $\mathrm{N}^{\mathrm{pro}}, \mathrm{C}, \mathrm{E}^{\mathrm{rns}}, \mathrm{E} 1$, E2, and p7. Non-structural proteins are encoded downstream: NS2-3, NS4A, NS4B, NS5A, and NS5B $(3,5,6)$. The vast majority of BVDV field isolates do not induce cytopathology in cell culture and are called non-cytopathic (ncp); cytopathic (cp) isolates are found almost exclusively in cattle suffering from mucosal disease $(6,7)$.Many antigen-capture ELISA's have been developed for detection of BVDV antigen. The most commonly used antigen capture ELISA uses Mab directed against a conserved antigenic domain of a non- 
$\begin{array}{llll}\text { AL-Qadisiya Journal of Vet.Med.Sci. } \quad \text { Vol./11 } & \text { No./2 }\end{array}$

structural protein (NS2/3) of pestiviruses. Serum is a good sample for the detection of infected animals by antigen-capture ELISA [8]. These antigen-capture ELISA have been found to yield results comparable to those of virus isolation $[8,9]$. Several molecular diagnostic tests (RT-PCR) have been described for the detection of BVDV in serum, tissues, and isolates. Most of these tests are based on the detection of 5'UTR region or E2 gene [8]. A number of tests have developed for identification of BVDV and differentiation of BVDV1, BVDV2, and BDV [10, 11, 12, 13].Both BVDV genotypes have been reported in North America [14, 15], South America (Brazilian) [16], Europe (Germany; Belgium; Slovakia; United Kingdom, Austria, Italy) $[17,18,19,20,21$, 22, 23], Asia (Japan) [24].In republic of Iraq, very little studies about BVDV, but some research revealed that first demonstrated of disease in year 1977 (25).Identified BVDV antibodies in cattle from different areas in Iraq. In year 2004 demonstrated cytopathogenic strain in cultured cells in vitro(26). Another study detected the virus in buffalos and cow herds, also demonstrated persistent infection (27).

\section{Material and methods}

Two hundred eighty blood samples collected from non-vaccinated cattle herds in Nassirya city (188 samples) and Basrah city (92 samples) south of Iraq. Samples were collected in $10 \mathrm{ml}$. vacuum tubes without anticoagulant and centrifuged at $2500 \mathrm{rpm}$ for 20 minutes in order to obtain sera samples. The sera samples were refrigerated and tested as soon as possible.

\section{1-ELISA:}

After obtained serum from blood samples. They are testing by using a commercial kit IDEXX HerdCheck ELISA BVDV Antigen Test. The test was realized as manufacturer's instructions. Results were read by spectrophotometer by $450 \mathrm{~nm}$. Wave length. All samples submitted to direct and indirect Elisa(IDEXX Herd Check ELISA ) for detect BVDV antibodies.

\section{2-Real time PCR:}

In this method were included two steps firstly by extraction RNA from each sample by using QIAamp RNA Mini Kit (supplied by Qiagen company). After extraction of RNA followed manual procedure supplied with kit.Second step was amplification of extracted RNA in real time quantitive-PCR system (7300 Real time PCR Biotechnol. System) using QIAamp Cador BVDV1/2 kit (supply by Qiagen company) which is differentiated of three different viruses in same kit include BVDV 1, BVDV2 and Border disease.Under the manual book supplied with kit steps and after fifty cycles, read the qaulificated product by the same procedure of manufacturer's. The method was done under restricted sterile conditions to prevent contamination of samples and amplification RNA.
Results of the first step of the study revealed that 20 positive samples according to direct Elisa(Ag detection) test (8 in samples from Nassirya city while 12 samples

\section{Results}

were positive in Basrah city), while 66 samples were positive to indirect Elisa( $\mathrm{Ab}$ detection) Table(1).

Table(1): show results of direct and indirect Elisa test in cows serum samples

\begin{tabular}{|c|c|c|c|c|}
\hline Elisa test & Positive samples & $\%$ & Negative samples & Total \\
\hline Direct Elisa $(\mathrm{Ag})$ & 20 & 7.14 & 260 & \multirow{2}{*}{280} \\
\hline Indirect Elisa $(\mathrm{Ab})$ & 66 & 23.57 & 214 & \\
\hline
\end{tabular}


$\begin{array}{llll}\text { AL-Qadisiya Journal of Vet.Med.Sci. } & \text { Vol./11 } & \text { No./2 }\end{array}$

The results of real time-qPCR, after extraction RNA from samples exhibited that only two positive samples detected from the
20 samples as BVDV type one .as following in figures.

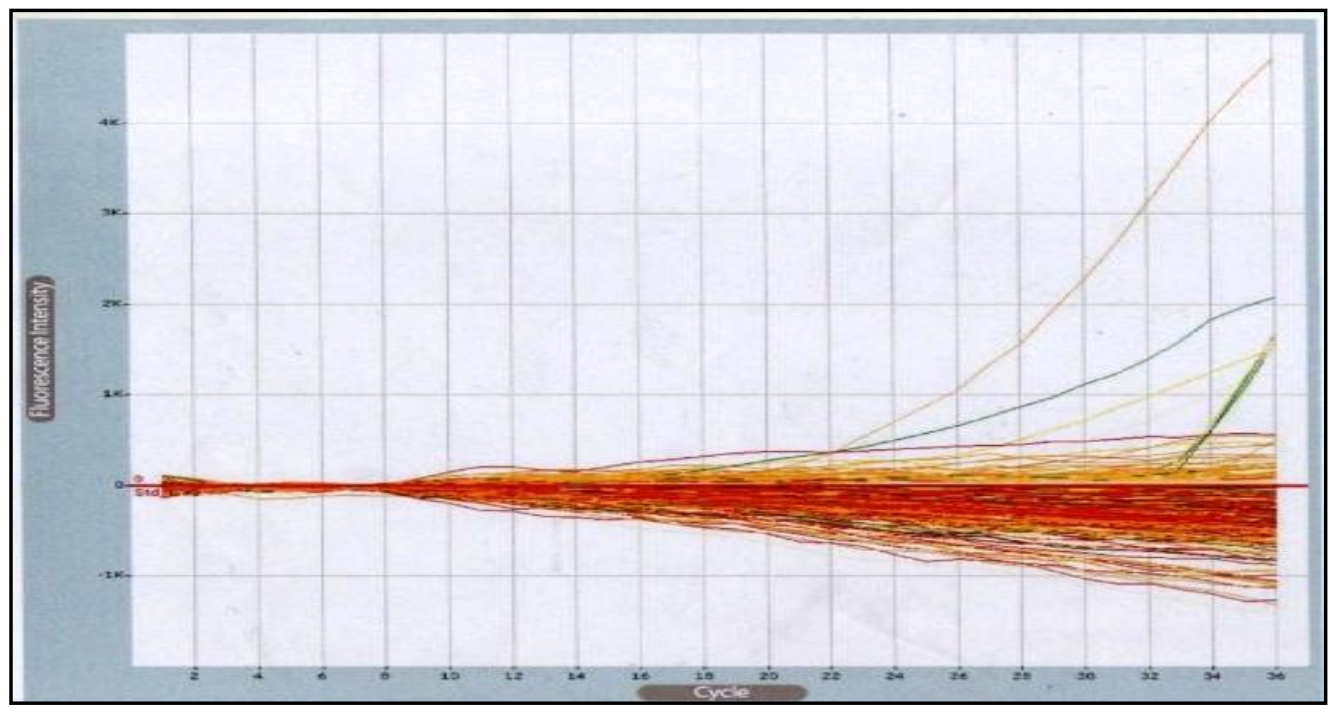

Fig.(1):positive tow samples of BVDV1 yellow lines, while blue line represent positive control of BVDV1.

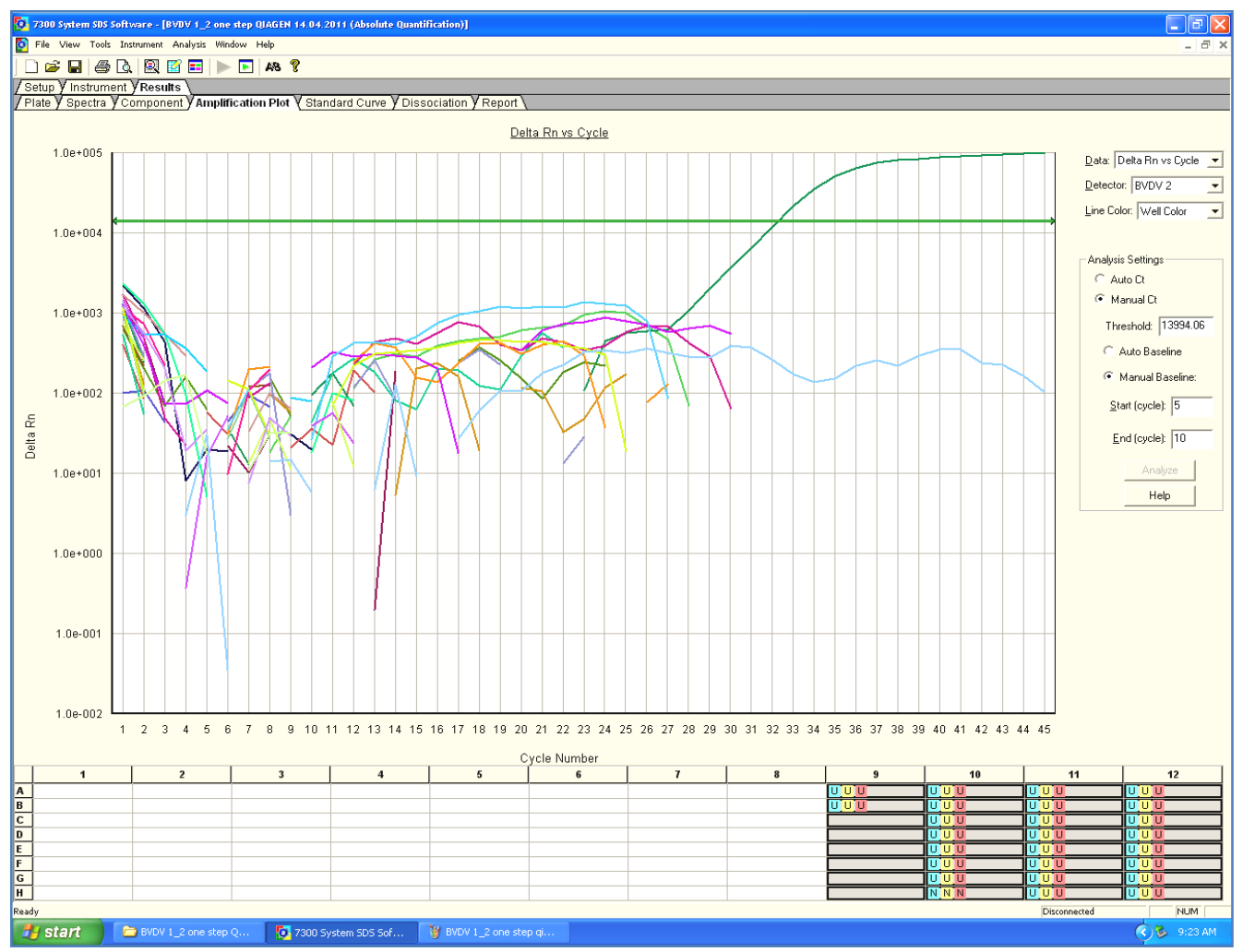

Fig.(1): negative results to BVDV type 2, green curved line represent positive control to BVDV2 


\section{Discussion}

The results revealed that $20(7.14 \%)$ samples were positive to direct Elisa(Ag detection) test (8 in samples from Nassirya city and 12 samples in Basrah city), while 66 (23.57\%) samples were positive to indirect Elisa( $\mathrm{Ab}$ detection). Our result, are in accordance with other studies in Iraq by using same test, but are different when compared with $89.80 \%$ in Konya, $72.25 \%$ in Mashhad(28) that's may be attributed to animals density.RT-qPCR give better results than the other techniques, it is give as true positive results if keep restricted from contamination and follow procedure well.The RT-PCR method had the advantage of ascertaining BVDV nucleic acid sequences in samples in which the virus had been inactivated, e.g. during transport or storage or due to the presence of neutralizing antibodies (29).And that give the answer why ELISA test was not $100 \%$ positive results, also the presence of antibodies will interfere with the test. As a result, it should not be used with animals less than three months of age (30). In cattle populations BVDV-1 strains are predominant in most part of the world, whereas BVDV-2 is recognized as the cause of severe acute haemorragic disease in North America being recently reported in Europe and Asia with low virulence (31).In our study there are wide range between ELISA results and PCR and this may be due to that RNA viruses are have low stability.Our result of RT.PCR show 2 positive samples $(10 \%)$ out of 20 samples are near of similar study results (11.1\%) done in Iran-Mashhad in 2007 by tank using bulk milk samples(32)The selection of herds in this study was based on randomization and we can expect to generalize this prevalence from our samples for two cities (nassirya- basrah) investigation of the influence of herd on BVDV distribution revealed that only one herd from each city were infected by BVDV, These results show that BVDV can be found in its minimum ratio, but a recent or an ongoing viremic most likely occur due to presence of Persisting Infection cattle which can distribute the BVD virus in other herds and regions(32) . Although from the low ratio of the PCR test result, a positive result would provide useful information. Positive PCR results would be weighted more heavily than negative results. The use of this assay may be most beneficial as a method of focusing on or justifying BVDV-positive herds for development of control strategies and not as a definitive test to ensure BVDV negative herd.It can be concluded that BVDV infection is an important disease in cattle of some region in south of Iraq. These herds include presence of PI animals which play an important role in spreading infection in the herd, because they act as life-long producers of the virus and do not induce the production of BVDV-specific antibodies (33). These results indicate that RT-PCR analysis of blood samples may provide a rapid and sensitive screening method for the detection of BVDV infections in nonvaccinated cattle herds. They also indicate that BVDV may be highly prevalent in cattle herds in the south of Iraq.

\section{References}

1. Horzinek, M.C. (1991). Pestiviruses taxonomic perspectives. Arch Virol.; 3 (1): 1- 5.

2. Francki, R.I.B.; Fauquet, C.M.; Knudson, D.L. and Brown, F. (1991). Classification and nomenclature of viruses. Fifth report of the International Committee on the
Taxonomy of Viruses. Arch Virol; 2: 223-233.

3. Collett, M.S.; Larson, R.E. and Gold, C.(1988). Molecular cloning and nucleotide sequence of the Pestivirus bovine virus diarrhea virus. Virology; 70: 253-266. 
4. Poole, T.L.; Wang, C.; Popp, R.A.; Potgieter, L.N.; Siddiqui, A. and Collett, M.S. (1995). Pestivirus translation initiation occurs by internal ribosome entry. Virology; 206: 750-754.

5. Collett, M.S.; Larson, R.; Belzer, S.K. and Retzel, E.( 1988). Proteins encoded by bovine viral diarrhea virus: the genomic organization of a Pestivirus. Virology; 165: 200208.

6. Donis, R.O.(1995). Molecular biology of bovine viral diarrhea virus and its interactions with the host. Vet Clin North Am Food Anim Pract.; 11: 393-423.

7. Goyal, S. M.;. Ames, G. M.; Barrington, K. V. ; Brock, B. M.; Crossley, D.; Deregt, J. F.; Evermann, R. W.; Fulton, M. D.; Givens, , D. L.; Grooms, S. K.; Hietala, H.; Houe, S.; Kapi, R. L.; Larson, E. M.; Liebler-Tenorio, H.; Minocha, J.D.; Neill, J. F.; Ridpath, M. C.; Thurmond, P.; Walz, M. and Wilkerson, M.(2005). Bovine Viral Diarrhea Virus, Diagnosis, Management, and Control, Edited by S. M. Goyal and J. F. Ridpath, Blackwell Publishing Professional, 2121 State Avenue, Ames, Iowa 50014, USA.Pp:1- 243.

8. Greiser-Wilke, I.; Dittmar, K.E.; Liess, B. and Moennig, V.(1992). Heterogeneous expression of the nonstructural protein $\mathrm{p} 80 / \mathrm{p} 125$ in cells infected with different pestiviruses. J Gen Virol 73:47-52. Horzinek MC. Pestiviruses taxonomic perspectives. Arch Virol.; 3 (1): 1-5.

9. Sandvik, T. and Krogsrud, J. (1995). Evaluation of an antigen capture ELISA for detection of bovine viral diarrhea virus in cattle blood samples. J Vet Diagn Invest.; 7:6571.
10. Fulton, R.W. d'Offay, J.M. and Saliki, J.T.(1999). Nested reverse transcriptase-polymerase chain reaction (RT-PCR) for typing ruminant pestiviruses: Bovine viral diarrhea viruses and border disease virus. Can J Vet Res.; 63:276-281

11. Letellier, C. and Kerkhofs, P. (2003). Real-time PCR for simultaneous detection and genotyping of bovine viral diarrhea virus. $J$ Virol Methods; 114:21-27.

12. Ridpath, J.F.; Bolin, S.R. and Dubovi, E.J.(1994). Segregation of bovine viral diarrhea virus into genotypes. Virology; 205:66-74.

13. Sullivan and Akkina, R.K.( 1995). A nested polymerase chain reaction assay to differentiate pestiviruses. Virus Res.; 38:231-239.

14. Bolin, S.R.; Ridpath, J.F.; Black, K.; Macy, M. and Robin.(1994). Survey of cell lines in the American Type Culture Collection for bovine viral diarrhea virus. J. Virology Metods; 1994, 48, 211-221.

15. Fulton, R. W.; Ridpath, J. F.; Sharon Ore; A. W.; Confer; J.T.; Saliki, L.J.; Burge; Payton, M.(2005). Bovine viral diarrhea virus (BVDV) subgenotypes in diagnostic laboratory accessions: Distribution of BVDV1a, 1b, and 2a subgenotypes. Veterinary Microbiology; 111, 35-40.

16. Flores, E.F.; Weiblen, R. and Gil, L.H.V.G. (2000). Antigenic diversity of Brazilian isolates of bovine viral diarrhea virus (BVDV): Implications for diagnosis and immunization strategies. Arq Bras Med Vet Zootec, 52:11-17.

17. Wolfmeyer, A.; Wolf, G.; Beer, M.; Strube, W.; Hehnen, H-R.; Scmeer, N. And Kaaden, O-R.(1997). Genomic (5'-UTR) and serological differences among BVDV field 
isolates. Arch. Virol.; 142: 20472049.

18. Tajima, M.; Frey, H.R. and Yamato, O. ( 2001). Prevalence of genotypes 1 and 2 of bovine viral diarrhea virus in Lower Saxony, Germany. Virus Res.; 76:31-42.

19. Couvreur, B.; Letellier, C.; Collard, A.(2002). Genetic and antigenic variability bovine viral diarrheavirus (BVDV) isolates from Belgium. Virus Res.; 85:1728.

20. Vilcek, S.; Durkovic, B.; Bobakova, M.(2002). Identification of bovine viral diarrhoea virus 2 in cattle in Slovakia. Vet Rec.; 151:150-152.

21. Vilcek, S.; Greiser-Wilke, I.; Durkovic, B.; Obritzhauser, W.; Deutz, A. And Köfer, J.(2003). Genetic diversity of recent bovine viral diarrhoea viruses from the southeast of Austria (Styria). Vet. Microbiol.; 91: 285-291.

22.Drew, T.W.; Sandvik, T.; Wakeley, P. ( 2002). BVD virus genotype 2 detected in British cattle. Vet Rec.; 151:551-551.

23.Pratelli, A.; Martella, V.; Cirone, F.; Buonavoflia, D.; Elia, G.; Tempesta, M.; Bionavoglia, C.(2001). Genomic characterization of pestiviruses from lambs and kids in Southern Italy. J. Virol. Meth.; 94: 81-85.

24. Nagai, M.; Ito, T.; Sugita, S.; Genno, A.; Takeuchi, K.; Ozawa, T.; Sakoda, Y.; Nishimori, T.; Takamura, K. And Akashi, H.(2001). Genomic and serological diversity of bovine viral diarrhea virus in Japan. Arch. Virol.; 146: 685-696.

25.Hashemi, G.R.; Tabar , A.; Haghparast and Naseri, Z. (2010). Prevalence of Bovine Viral antibodies and antigen among the aborted dairy Cows in industrial dairy cattle herds in Mashhad area-Iran. World applied science journal; 8(5):Pp635-640.

26. Talebkhan,_M. ; Garoussi, A.; Haghparast and Hajenejad, $M$. R.(2008). Prevalence of Bovine Viral Diarrhoea Virus antibodies among the industrial dairy cattle herds in suburb of Mashhad-Iran. Tropical Animal Health and Production; 41(4): 663-667, DOI: 10.1007/s11250-008-9238-y.

27. El-Kholy, A.A.; Bolin, S.R.; Ridpath, J.F.,; Arab, R.M.; Abou-Zeid, A.A. and Platt, K.B.( 1998). Use of polymerase chain reaction to simultaneously detect and type bovine viral diarrhoea viruses isolated from clinical specimens. Rev. Sci. Tech.; 17: 733-742.

28. Laamanen, U.I.; Neuvonen, E.P.; Yliviuhkola, E.M. and Veijalainen, P.M.(1997). Comparison of RTPCR assay and virus isolation in cell cultures for the detection of bovine viral diarrhoea virus (BVDV) in field samples. Res. Vet. Sci.; 63: 199-203.

29. Bezek, D.M.(1995). Bovine Virus Diarrhea Virus Infection:

Individual and Herd Diagnosis. The Compendium: s57-s62.

30. Letellier, C.; Kerkhofs, P.; Wellemans, G. And Vanodenbosch, E.( 1999). Detection and genotyping of bovine viral diarrhea virus by reverse transcription-polymerase chain amplification of the 5' untranslated region. Vet. Microbiol.; 64: 155167.

31. Luzzago, C.; Bandi, C.; Bronzo, V.; Ruffo, G.; Zecconi, A.( 2001). Distribution pattern of bovine viral diarrhoea virus strains in intensive cattle herds in Italy. Vet. Microbiol.;83(3):265-74.

32. Trevor, W.D.; Yapp, F. and Paton, D.J.(1999). The detection of bovine viral diarrhoea virus in bulk milk 
samples by the use of a single-tube

RT-PCR. Vet Microbiol.; 64:145-

154.

33. Houe, H. and Meyling, A. (1991).

Prevalence of bovine virus diarrhea
(BVD) in 19 Danish dairy herds and estimation of incidence of infection in early pregnancy. Prev Vet Med.; 11: 9-16.

\section{انتشار فيروس الإسهال البقري الحمي في قطعان الماثية من محافظات البصرة

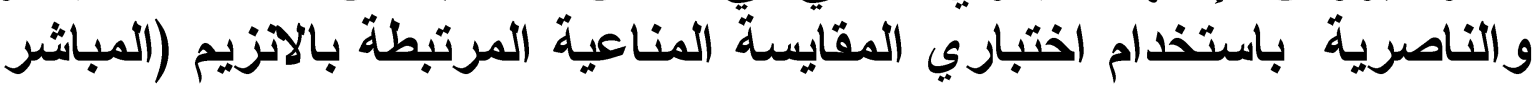 وغير المباشر) وتفاعل سلسلة البلمرة نوع (RT-PCR)}

$$
\text { جاسمة عبد الحسين جار الله بل }
$$

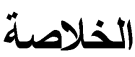

أجريت الدراسة الحالية للاستقصاء عن مدى انتشار حميات مرض الإسهال ألبقري الحمي عن طريق استخدام اختباري المقايسة المناعية المرتبطة بالنزيم (ELISA)وكذلك اختبار تفاعل سلسلة البلمرة نوع(RT-PCR). وثمانون عينة تم جمعها من الأبقار غير الملقحة ضد مرض الإسهال الفيروسي من محافظتي البصرة و الناصرية (188)

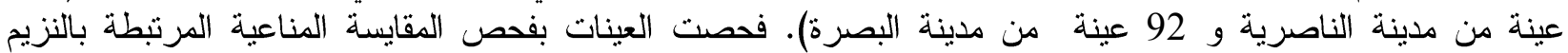

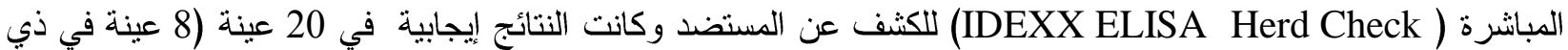
قار و 12 عينة في البصرة) وبنسبة إصابة بلغت

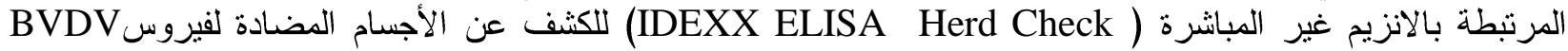
وكانت نسبة الإصابة 23.57\%. و واجزي التتميط الجيني لجميع العينات الإيجابية لفحص المستضد باستخدام اختبار

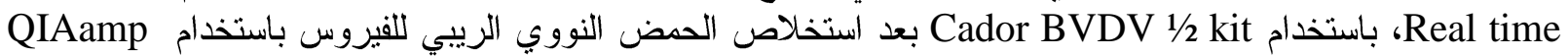
mini kit أظهرت النتائج لفحص المقايسة المناعية المرتبطة بالنزيم وجود 20 عينة موجبة للاختبار المبانشر و66 عينة

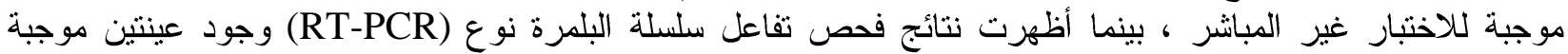
للنوع 1 من حميات مرض الإسهال ألبقري الحمي (نموذج واحد لكل مدينة). 